\title{
Beneficial effect of an indwelling foley-catheter for the treatment of chronic endometritis caused by cervical adhesions in an American Quarter Horse mare - a case report
}

\author{
Stefanie Neuhauser und Johannes Handler
}

Klinik für Pferde, Freie Universität Berlin

\begin{abstract}
Summary
A 15 -year-old Quarter Horse mare was presented with a sterile pyometra caused by cervical adhesions. In addition to the commonly used endometritis therapy, a Foley-catheter was permanently placed in the cervical canal to facilitate uterine drainage and to prevent cervical adhesions until lesions were healed. The mare never showed estrus behavior and repeated examinations revealed a persistent corpus luteum on the left ovary.
\end{abstract}

Keywords: mare, cervical lesions, chronic endometritis, pyometra, foley-catheter

Positiver Effekł eines Langzeit-Foley-Katheters für die Behandlung einer chronischen Endometritis aufgrund von Adhäsionen der Zervix bei einer American Quarter Horse-Stute - ein Fallbericht

Eine 15-jährige Quarter Horse Stute wurde wegen Koliksymptomatik vorgestellt. Die Untersuchung ergab eine sterile Pyometra aufgrund von Verklebungen und Verwachsungen in der Zervix und einen aufgegasten Dickdarmteil ventral des linken breiten Mutterbandes. Zusätzlich zu der üblichen Endometritis-Therapie wurde ein Foley-Katheter für längere Zeit im Zervikalkanal liegen gelassen, um die Entleerung des Uterusinhaltes zu ermöglichen und die Läsionen in der Zervix ohne erneute Adhäsionen verheilen zu lassen. Die Stute zeigte über mehrere Monate keine Rossesymptome und einen persistierenden Gelbkörper am linken Ovar.

Schlüsselwörter: Stute, Zervixverletzung, chronische Endometritis, Pyometra, Foley-Katheter

Pyometra in the mare is defined as an accumulation of large quantities of inflammatory exsudate in the uterus caused by cervical anomalies, impaired uterine clearance or infection (Hughes et al. 1979, LeBlanc 1994, Santschi et al. 1995, Pycock 2007). In mares, pyometra is usually not associated with systemic disease. However, acute inflammation of the uterus often causes shortened estrous cycle, but prolonged inflammation with severe destruction of the endometrium may lead to failure of prostaglandin synthesis and prolonged luteal phase (Hughes et al. 1979).

Cervical trauma may occur in case of dystocia or breeding injury and contributes to infertility. The cervix is a thick walled sphincter. Expansion and contraction are possible due to the action of longitudinal and circular smooth muscles, which are rich of elastic fibers. Size, consistence and shape vary according to hormonal changes during the estrous cycle. Failure of the cervix to open accompanies predisposition for chronic endometritis (Pycock und Ricketts 2007).

Endometrial release of prostaglandin F2 $\alpha$ (PGF2 $\alpha$ ) causes luteolysis in normal cycling mares. Ovarian steroids may be required to act on the endometrium for a minimum interval before PGF2 $\alpha$ is released. Oxytocin also plays an important role on endometrial secretion of PGF $2 \alpha$. In mares, higher circulating oxytocin levels and increased number of oxytocin receptors in the endometrium during late luteal phase have been shown to stimulate PGF2 $\alpha$ synthesis and secretion (Gin- ter 1992). Hence, uterine infections can influence luteal lifespan in mares (Hughes et al. 1979, Neely et al. 1979) due to altered endometrial prostaglandin release.

Currently recommended for treatment of endometritis in the mare is the use of ecbolic agents such as oxytocin and PGF2 $\alpha$ to improve uterine clearance, uterine lavage, promoting cervical drainage by manual dilatation or the local use of prostaglandin E and antibiotic treatment (LeBlanc und Causey 2009).

In the present case, standard therapy of endometritis with ecbolic drugs, uterine flushes, estrus induction, antibiotic and anti-inflammatory medication was not successful unless, due to adhesions in the cervix, uterine drainage was ensured by a transcervical foley catheter.

\section{Case description}

A 15-year-old American Quarter Horse mare was presented at the Clinic for Horses (Day 1), because she showed moderate to severe signs of abdominal pain. The mare had developed repeated episodes of endometritis after natural service approximately one year before. Treatments had started almost twelve months before and were terminated approximately six months prior to the admission to the clinic. However, a detailed history of preceding endometritis therapy was not availa- 
ble. According to the owner's report, the mare has never exhibited symptoms of colic before. The mare was not primarily a breeding mare and had never had a foal before. The major interest of the owner was the salvage of the animal.

The mare was in good body condition and the rectal temperature was within the normal range $\left(37.5-38.0^{\circ} \mathrm{C}\right)$. Heart rate

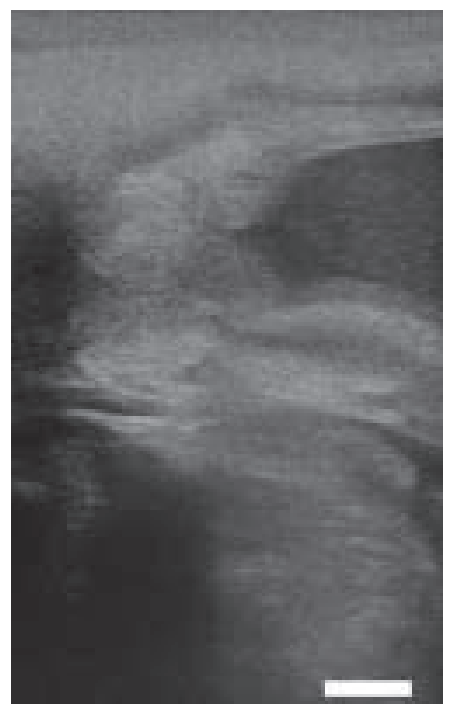

Fig. 1 Transrectal ultrasound examination: fluid accumulation in the uterus right cranial to the cervix (Day 1, bar $=10 \mathrm{~mm}$ ).

Transrektale Ultraschalluntersuchung: Flüssigkeitsansammlung im Corpus uteri unmittelbar kranial der Zervix (Tag 1, Balken=10 mm).

( $H R$, 48 beats per minute; normal range 28-40) and respiratory rate (RR, 16 breaths per minute; normal range 10-14) were increased at the arrival but had returned to normal values quickly (HR 32 beats per minute; RR 8 breaths per minute). Hematology showed mild leucocytosis (11.43×109 leucocytes/L; normal 5-10x10\%/L). Rectal examination revealed an enlarged fluid-filled uterus. The ligamenta lata uteri were tense. Ventral to the left uterine ligament, the distended pelvic flexure of the large colon was palpable. Transrectal ultrasound examination (MyLabFiveVet, Esaote Biomedica, Köln, Germany) confirmed echoic fluid in the uterus without pregnancy (Fig. 1 and 2) and showed a corpus luteum on the left ovary. Vaginal examination revealed a tightly closed, stenotic cervix. The course of the cervical canal was not straight, but the cranial part sharply turned ventrally, and circumferential tight rings of fibrotic tissue formed a diverticulum in the middle of the cervix. Manipulation of the cervix caused little trauma and bleeding.

At the day of presentation (Day 1), the cervix was gently dilated and adhesions separated manually. A catheter was inserted into the uterus and approximately twelve litres of pus discharged spontaneously. Subsequently, the uterus was flushed with saline and luteal regression was induced by a single dose of dinoprost (5 mg IM, Dinolytic $5 \mathrm{mg} / \mathrm{ml}$ Injektionslösung, Pfizer, Puurs, Belgium). Immediately after uterine flushing, the mare stopped to show any symptoms of colic. The uterus became smaller and the gaseous ascending colon disappeared. The wall of the uterine horns was thickened and strongly contracted. The cervix appeared almost four fingers in diameter, distinct, firm and toned at rectal palpation. Twelve hours after initial treatment (Day 1), a slightly clouded fluid accumulation - up to $44 \mathrm{~mm}$ in diameter - in the uterine lumen was detected ultrasonographically. Cytological examination of the uterine fluid yielded polymorph nuclear granulocytes (PMNs) as predominating cells. Microbiological examination of the uterine secretion revealed neither bacterial (aerobic and anaerobic) nor mycological growth.

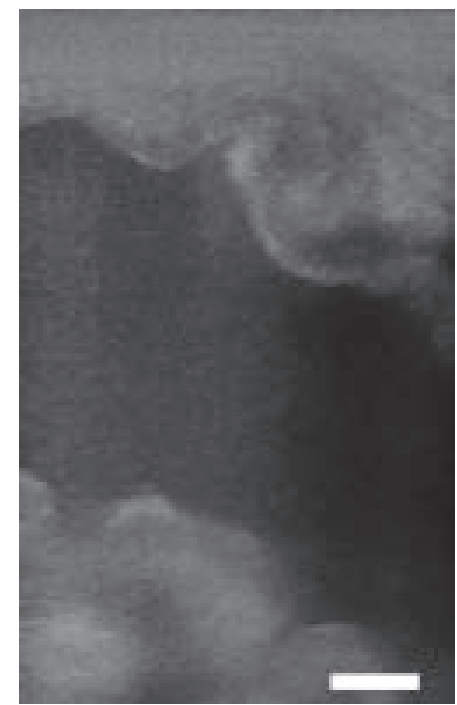

Fig. 2 Transrectal ultrasound examination: accumulation of echoic fluid in the corpus uteri (Day 1, bar=10 mm).

Transrektale Ultraschalluntersuchung: Ansammlung von echogener Flüssigkeit im Corpus uteri (Tag 1, Balken=10 mm).

At the following day (Day 2), the uterus was fluid-filled and the cervix was closed making it difficult even to pass a finger. Because the uterine drainage via the cervix was not possible, we inserted a Foley-catheter (Silkolatex $30 \mathrm{cmx} 10 \mathrm{~mm}, 5-15$ ml balloon, Rüsch Gold, Tele-flex Medical, Kernen, Germany) into the uterus (Fig. 3), which remained in situ for more than three weeks. The mare was treated daily with oxytocin (10 IE q 6 h, IV, Oxytocin Albrecht, Albrecht, Aulendorf, Germany) until Day 20. Additionally she received antiinflammatory drugs for five days (Days 13 to 17; flunixin meglumine $1.1 \mathrm{mg} / \mathrm{kg}$ bwt, orally, Finadyne-Paste, Intervet, Unterschleißheim, Germany).

At Day 3, sonographic examination revealed less amount of fluid and some air in the uterus, and the uterine wall appeared slightly heterogeneous similar to a starfish like texture. The endometrial surface was hyperechoic and in the area of air accumulation comet tail artifacts were visible indicating an irregular surface structure.

Uterine lavages with saline were repeated on Days 4 and 6, and daily between Days 9 and 13. Frequency of uterine flushing depended on quantity and quality of uterine fluids obtained. Quality of the uterine fluid changed from purulent to a mucous containing flocculent material (Days 9 to 11), to bloody (Days 12 to 15) and mucous and bloody (Days 18 and 19). From then, no further uterine discharge was detected at the follow-up examinations. Ultrasonographically, in the uterine lumen, some fluid was present until Day 19. Occasionally, some air could be detected until Day 17 and on Days 29 and 31. The uterine wall was still of heterogeneous texture on Day 22 with a layered appearance present- 
ed by a hypoechoic area between endo- and myometrium. In the center of cross-sectional images of the uterine horn, a hyperechoic line was visible, indicating the localization of the endometrial surface. From Day 23 to 27, the structure of the uterine wall changed slightly. The endometrium demonstrated as hypoechoic and - in a patchy way, but not layered heterogeneous, non-edematous structure.

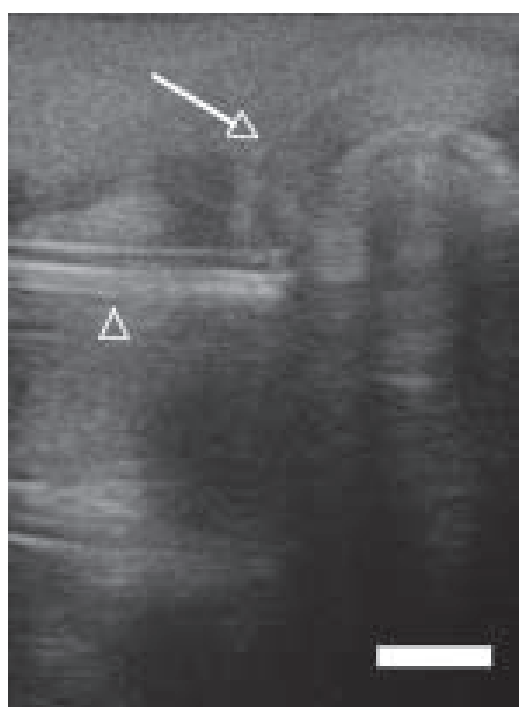

Fig. 3 Transrectal ultrasound examination: longitudinal section of the cervix presenting a Foley-catheter (balloon=arrow; catheter= arrowhead) in the cervical canal (Day 22; bar $=10 \mathrm{~mm}$ ).

Transrektale Ultraschalluntersuchung: Längsschnitt der Zervix mit eingelegtem Foley-Katheter (Ballon=Pfeil; Katheter=Pfeilspitze) im Zervikalkanal (Tag 22, Balken=10 mm).

Ovulation was detected 17 days after prostaglandin administration. During all subsequent examinations (Days 21, 22, $23,27,29,32)$, a $C L$ was noticed on the left ovary and the uterine echotexture was characteristic for diestrus.

On Day 18 a second microbiological analysis revealed betahemolytic and non-hemolytic streptococci. Due to the result of bacterial sensitivity testing, the mare was treated with cefquinom $(1.0 \mathrm{mg} / \mathrm{kg}$ bwt, intravenously, Cobactan 4,5\%, Intervet, Unterschleißheim, Germany) for seven days (Days 21 to 27). The Foley-catheter was removed at Day 26. After removal of the foley-catheter, the majority of the cervix presented an inhomogeneous structure with a hypoechoic area in the middle of the cervical canal, which remained visible at least up to Day 48 (Figure 4).

From first admission the mare remained hospitalized for 33 days. Major findings and treat-ments from Day 1 to 20 are shown in Table 1. Follow-up examinations were performed at Days 42, 48 and 77. During all subsequent examinations

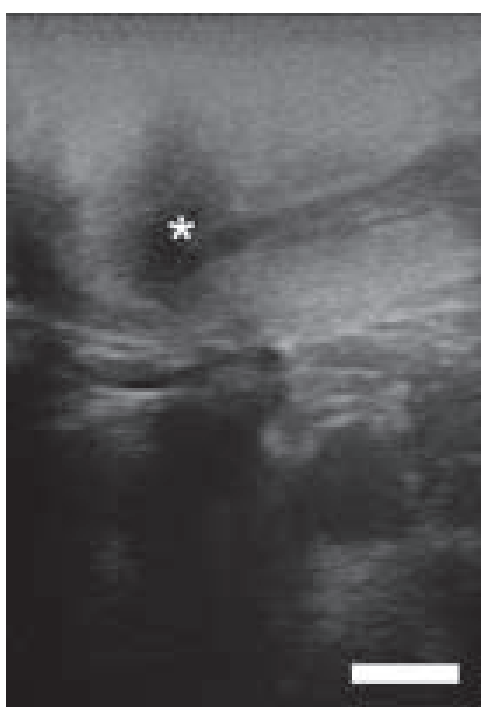

Fig. 4 Transrectal ultrasound examination: longitudinal section of the middle and cranial cervix, hypoechoic cervical canal and hypoechoic appearance of all layers (asterisk) in the middle of the cervix (Day 48; bar $=10 \mathrm{~mm}$ )

Transsrektale Ultraschalluntersuchung: Längsschnitt des mittleren und kranialen Bereichs der Zervix mit dem hypoechogenen Zervikalkanal und der hypoechogenen Darstellung aller Schichten (Stern) im mittleren Abschnitt der Zervix (Tag 22, Balken=10 mm).

the left ovary presented a CL and the echotexture of the uterus was inhomogeneous and from Day 42 a hyperechoic line marked the endometrial surface. At the examination on Day 77 the endometrial surface appeared still a bright line. The endometrium was hypo- and the myometrium hyperechoic. The uterine wall was slightly layered, but there was no clear border in between. No fluid accumulation in the uterine lumen could be detected. The cervical canal presented hyperechoic, but the cervix was not in a straight position and a longitudinal sonographic section could not be obtained.

Table 1 Diagnostic findings and treatments of the mare from Day 1 to 20

\begin{tabular}{|c|c|c|c|c|c|c|c|c|c|c|c|c|c|c|c|c|c|c|c|c|}
\hline & \multicolumn{20}{|c|}{ Days } \\
\hline & 1 & 2 & 3 & 4 & 5 & 6 & 7 & 8 & 9 & 10 & 11 & 12 & 13 & 14 & 15 & 16 & 17 & 18 & 19 & 20 \\
\hline$A$ & +++ & + & & + & + & + & + & + & + & + & + & + & + & + & - & - & + & + & $(+)$ & \\
\hline B & - & ++ & & + & ++ & - & - & + & - & + & - & + & + & + & - & + & $(+)$ & - & - & \\
\hline C & purulent & & & & & & & & & loccu & & & & & & & & blood & Jcoid & \\
\hline $\mathrm{D}$ & & & & & & & & & & & & & & & & & $\mathrm{CL}$ & & & \\
\hline$E$ & $\mathrm{fl}$ & & & $\mathrm{fl}$ & & $\mathrm{fl}$ & & & & & erine & ush & & & & & & & & \\
\hline$F$ & swab & & & & & & & & & & & & & & & & & swab & & \\
\hline$G$ & & & & & & & & & & & & & & & unixi & & & & & \\
\hline $\mathrm{H}$ & PGF2 $\alpha$ & & & & & & & & & & & oxyto & & & & & & & & \\
\hline
\end{tabular}


According to the owner's report the mare has not shown estrus behavior until at least Day 99.

\section{Discussion}

Cervical adhesions usually occur after dystocia or mating by natural service. Further, severe inflammation and intrauterine use of irritating agents are possible causes. Scarring of the cervical wall causes deformity and stenosis and the cervix subsequently may fail to dilate. Interference to the physiological drainage of intraluminal fluid accumulations from the uterus and the inefficiency of the sphincter function leads to infertility (Thornbury 1975, Sertich 1993, Estrada und Samper 2007). In the present case, natural service was most likely the initial cause for cervical laceration and chronic endometritis. However, we cannot rule out that previous endometritis treatments have contributed to cervical damage.

Mucosal defects of the cervix are treated by digital massage to prevent adhesions (Pycock und Ricketts 2007). After manual breakdown of the fibrous tissue by blunt dissection, adhesions regrow rapidly (Sertich 1993), and complete resolution of a cervical adhesion is rarely achieved (Sertich 2007, 2011 ). In literature, different opinions concerning the benefit of the use of indwelling catheters are present (Sertich 1993, 2007,2011 ). We used a balloon-catheter, which remained in its position for several weeks to avoid re-adhesion of the cervical lumen and to enable discharge of uterine fluids.

Ultrasound examination of a normal cervix in diestrus reveals a well demarcated, hyperechoic texture. During estrus, the cervix is less distinct, relaxed, looses some of its echogenicity and the cervical lumen is more likely to be visualized (Brinsko et al. 2010). Handler et al (2003) reported local changes of the sonographic appearance of the cervix for one to three days after dilation with a balloon catheter. The course of white longitudinal lines representing attached longitudinal folds of the cervix became interrupted at the local site of the balloon. In the present case, we also observed similar changes of the sonographic appearance of the cervix after removal of the Foley-catheter.

Pyometra may occur due to cervical abnormalities (Santschi et al. 1995). It is usually not accompanied by signs of systemic disease (Hughes et al. 1979, Murray und Peter 1991, Pycock 2007). Weight loss, depression, anorexia and discomfort during exercise were very occasional findings (Pycock 2007). Intervals between successive ovulations may be shortened, absent, normal or prolonged (Hughes et al. 1979). Colic in mares due to abnormalities of the reproductive tract usually occurs during late pregnancy, after parturition (e.g. uterine torsion, uterine rupture, hemorrhage into broad ligament or uterine wall) or mating injury (Sonyi 1962, Wheat und Meagher 1972, Barber 1979, Lofstedt 1994, Rossdale 1994). There is also one report on omental adhesions associated with the reproductive tract in a mare causing abdominal pain (Butson et al. 1996). In this case, the distended broad ligament strangulated the large colon causing colic symptoms.

The first uterine swab was negative for microorganisms and the second swab revealed streptococci strains susceptible to cefquinom. We cannot exclude that the bacterial contamination resulted from manipulations during diestrus. Progesterone causes local immune suppression and subsequent transcervical manipulations increase risk of uterine infection. Therefore, frequency of uterine flushing was performed dependent on ultrasonographic examinations and quality of preceding uterine lavage fluid. We used cephalosporins, due to antimicrobial sensitivity and sufficient enrichment in uterine tissue after parenteral application (Witte et al. 2010). We preferred parenteral antibiotic therapy, because intrauterine administration bears the risk of local irritation and fungal infection. Additionally, according to palpation and ultrasound findings, we suggested that deep layers of the uterine wall might be affected and systemic antibiotics penetrate the myometrium more easily compared to local antibiotic therapy, which may prevent diffusion into deeper tissue layers due to $\mathrm{pH}$ or biofilm (LeBlanc 2009).

Ovariohysterectomy was performed in mares with chronic pyometra associated with cervical anomalies (Santschi et al. 1995, Bartmann et al. 2003, Rötting et al. 2004). The owner decided against surgical intervention, because of the potential risk of life-threatening complications, e.g. peritonitis or severe hemorrhage, due to removal of the uterus in mares (Santschi et al. 1995). Further, genital adhesions causing colic can be detached by laparoscopy (Bartmann et al. 2006).

The success of treatment in case of pyometra can be assessed by endometrial biopsy or hysteroscopic evaluation of the endometrium (Murray und Peter 1991). We did not collect a uterine biopsy sample, because we did not want to take the risk of injury and subsequent adhesions of the cervix. The histological evaluation of the endometrium might have provided valuable information on the local changes associated with pyometra, which was not of that importance in this particular case, because the owner did not want to breed the mare again. However, we decided to examine the mare repeatedly by transrectal ultrasound only, because this is a wellestablished non-invasive technique (McKinnon et al. 1987).

One possible cause of the persistent corpus luteum is diminished prostaglandin release due to destruction of the endometrium (Hughes et al. 1979, Neely et al. 1979, Ginther 1989, 1990, Bartmann et al. 2003, Troedsson et al. 2003, McCue 2007). Additionally, repeated administration of oxytocin also could have interfered with luteal regression (Goff et al. 1987, Stout et al. 1999).

In conclusion, treatment of the pyometra and cervical adhesions by permanent catheterization of the uterine lumen has been demonstrated effective. However, the recurrence of pyometra due to impaired function of the cervix has still to be taken into account. Failure of luteolysis for several months possibly reflects severe endometrial damage caused by chronic inflammation.

\section{References}

Barber S. M. (1979) Torsion of the uterus - a cause of colic in the mare. Can. Vet. J. 20, 165-167

Bartmann C. P., Schiemann V., Poppe C. and Schoon H.-A. (2003) Partielle und radikale Hysterektomie beim Pferd. Tierärztl. Prax. 31 G, 6-15 
Bartmann C. P., Schiemann V. and Bubeck K. (2006) Laparoskopische Adhäsiolyse am Urogenitaltrakt des Pferdes. Pferdeheilkunde 22, 153-159

Brinsko S. P., Blanchard T. L., Varner D. D., Schumacher J., Love C. C., Hinrichs K. and Hartman D. (2010) Transrectal ultrasonography in broodmare practice. In: Manual of equine reproduction. Brinsko S. P., Blanchard T. L., Varner D. D., Schumacher J., Love C. C., Hinrichs K. und Hartman D. (Hrsg.) Mosby: Maryland Heights, Missouri: 3. Aufl., 54-72

Butson R. J., England G. C. W. and Blackmore C. A. (1996) Omento-omental adhesion around the uterine horn as a cause of recurrent colic in a mare. Vet. Rec. 139, 571-572

Estrada A. J. and Samper J. C. (2007) Cervical failure to dilate. In: Current therapy in equine reproduction. Samper J. C., Pycock J. F., und McKinnon A. O. Saunders: St. Louis, Missouri, 134-136

Ginther O. J. (1989) Regular and irregular characteristics of ovulation and the interovulatory interval in mares. J. Equine Vet. Sci. 9, 4-12

Ginther O. J. (1990) Prolonged luteal activity in mares - a semantic quagmire. Equine Vet. J. 22, 152-156

Ginther O. J. (1992) Endocrinology of the ovulatory season. In: Reproductive biology of the mare. Ginther O. J. Equiservices: Cross Plains, Wisconsin, 233-290

Goff A. K., Pontbriand D. and Sirois J. (1987) Oxytocin stimulation of plasma 15-keto-13, 14-dihydro prostaglandin F-2 $\alpha$ during the oestrus cycle and early pregnancy in the mare. J. Reprod. Fertil., Suppl. 35, 253-260

Handler J., Königshofer M., Kindahl H., Schams D. and Aurich C. (2003) Secretion patterns of oxytocin and PGF2 $\alpha$-metabolite in response to cervical dilatation in cyclic mares. Theriogenology 59, 1381-1391

Hughes J. P., Stabenfeldt G. H., Kindahl H., Kennedy P. C., Edqvist L.E., Neely D. P. and Schalm O. W. (1979) Pyometra in the mare. J. Reprod. Fertil., Suppl. 27, 321-329

LeBlanc M. M. and Causey R. C. (2009) Clinical and subclinical endometritis in the mare: both threats to fertility. Reprod. Dom. Anim. 44, 10-22

LeBlanc M. M. (1994) Oxytocin - the new wonder drug for treatment of endometritis? Equine Vet. Educ. 6, 39-43

LeBlanc M. M. (2009) The current status of antibiotic use in equine reproduction. Equine Vet. Educ. 21, 156-157

Lofstedt R. (1994) Haemorrhage associated with pregnancy and parturition. Equine Vet. Educ. 6, 138-141

McCue P. M. (2007) Ovarian abnormalities. In: Current therapy in equine reproduction. Samper J. C., Pycock J. F. und McKinnon A. O. Saunders: St. Louis, Missouri, 87-92

McKinnon A. O., Squires E. L., Carnevale E. M., Harrison L. A., Frantz D. D., McChesney A. E. and Shideler R. K. (1987) Diagnostic ultrasonography of uterine pathology in the mare. Proc. Am. Assoc. Equine Pract. 33, 605-622

Murray W. J. and Peter A. T. (1991) Uterine defense mechanisms and pyometra in mares. Compendium: Equine 13, 659-663
Neely D. P., Kindahl H., Stabenfeldt G. H., Edqvist L.-E. and Hughes J. P. (1979) Prostaglandin release patterns in the mare: physiological, pathophysiological, and therapeutic responses. J. Reprod. Fertil. Suppl. 27, 181-189

Pycock J. F. and Ricketts S. W. (2007) Perineal and cervical abnormalities. BEVA Equine Stud Medicine Course, 75-83

Pycock J. F. (2007) Therapy for mares with uterine fluid. In: Current therapy in equine reproduction. Samper J. C., Pycock J. F. und McKinnon A. O. Saunders: St. Louis, Missouri, 93-104

Rötting A. K., Freeman D. E., Doyle A. J., Lock T. and Sauberli D. (2004) Total and partial ovariohysterectomy in seven mares. Equine Vet. J. 36, 29-33

Rossdale P. D. (1994). Differential diagnosis of post parturient haemorrhage in the mare. Equine Vet. Educ. 6, 135-136

Santschi E. M., Adams S. B., Robertson J. T., DeBowes R. M., Mitten L. A. and Sojka J. E. (1995) Ovariohysterectomy in six mares. Vet. Surg. 24, 165-171

Sertich P. L. (2007) Cervical adhesions. In: Current therapy in equine reproduction. Samper J. C., Pycock J. F. und McKinnon A. O. Saunders: St. Louis, Missouri, 137-139

Sertich P. L. (1993) Cervical problems in the mare. In: McKinnon AO, Voss JL, eds. Equine Reproduction. Philadelphia: Lea \& Febiger, : 404-407

Sertich P. L. (2011) Cervix adhesions. In: Equine Reproduction. McKinnon A. O., Squires E. L., Vaala W. E. und Varner D. D. Wiley-Blackwell, Oxford, 2. Aufl., 2721-2723

Sonyi S. L. (1962). Rupture of the vagina in a mare during coitus. Can. Vet. J. 3, 298

Stout T. A. E., Lamming G. E. and Allen W. R. (1999) Oxytocin administration prolongs luteal function in cyclic mares. J. Reprod. Fertil. 116, 315-320

Thornbury R. S. (1975) Diseases of the vulva, vagina and cervix of the Thoroughbred mare. N. Z. Vet. J. 23, 277-280

Troedsson M. H. T., McCue P. M. and Macpherson M. L. (2003) Clinical aspects of ovarian pathology in the mare. Pferdeheilkunde $19,577-584$

Wheat J. D. and Meagher D. M. (1972) Uterine torsion and rupture in mares. J. Am. Vet. Med. Assoc. 160, 881-884

Witte T. S., Bergwerff A. A., Scherpenisse P., Drillich M. and Heuwieser W. (2010) Ceftiofur derivates in serum and endometrial tissue after intramuscular administration in healthy mares. Theriogenology $74,466-472$

Dr. Stefanie Neuhauser

Klinik für Pferde

Freie Universität Berlin

Oertzenweg $19 b$

14163 Berlin

neuhauser.stefanie@vetmed.fu-berlin.de 